\title{
Simposia en Konferensies
}

\section{Die chemie van geneesmiddels}

\author{
Simposium van die Afdeling Chemie van die Suid-Afrikaanse Akademie vir Wetenskap en \\ Kuns, 20 Mei 1988, Pretoria.
}

\section{Openingsrede}

\author{
M.H. Veldman \\ Departement van Nasionale Gesondheid en Bevolkingsontwikkeling, Privaatsak X9070, Kaapstad 8000
}

Mediese navorsing is ' $n$ multidissiplinêre poging. Chemici is nie alleen 'n belangrike skakel in hierdie interdissiplinêre ketting nie, maar maak ook 'n integrale deel van ander dissiplines uit.

Deur die eeue het twee duidelike rigtings in die geneeskunde ontwikkel: die volksgeneeskunde en die akademiese of skoolgeneeskunde. Die werklike deurbrake het egter eers in die negentiende eeu gekom en van toe af het die gaping tussen die volksgeneeskunde en die skoolgeneeskunde al vinniger vergroot. Die ontwikkeling en tegnologiese ewolusie van die natuurwetenskappe, veral chemie, en die veranderende sosio-ekonomiese struktuur van hierdie tydvak het groot momentum aan fundamentele navorsing gegee.

Dit het gou duidelik geword dat die ruimtelike konfigurasie van atome in 'n geneesmiddelmolekule 'n baie belangrike eienskap daarvan was. Chemici het toe struktuuraktiwiteitverwantskappe saam met die opklaring van struktuurformules begin navors. Nuwe analitiese metodes met betrekking tot die konformasie van ' $n$ bestanddeel was nie die enigste belangrike aspek nie en daar moes ook nuwe metodes vir die gradering en bestudering van die werkingsmeganismes van biologies aktiewe bestanddele gevind word.

Kennis van die chemie van geneesmiddels het nie net 'n invloed op middelontwikkeling en die optimale benutting van chemiese en analitiese metodologie uitgeoefen nie, maar dit het ook uitgekring na ander verwante velde en die ontstaan van nuwe wetenskappe. Die uitdaging waarvoor die uiteenlopende groepe chemici te staan gekom het, was om die verteenwoordigers van die verskillende velde van deskundigheid doeltreffend in 'n span te laat saam- werk. Kleinskaalse vervaardiging in apteke het verander in groot, industriële farmaseutiese ondernemings wat nuwe vereistes aan die vervaardigingsprosesse asook die eindprodukte gestel het.

Ongelukkig was die suksesverhaal van die chemie van geneesmiddels nie sonder terugslae nie, byvoorbeeld die sulfanilamiedtragedie toe meer as 100 kinders oorlede is as gevolg van die toediening van 'n sulfa waarvoor diëtileenglikol as oplosmiddel gebruik is, asook die talidomiedramp toe duisende babas met teratogene afwykings gebore is. Die wêreldwye probleem van die tientalle kinders en jongmense wat in die kloue van die onwettige verdowingsmiddelhandel beland, is waarskynlik minder ooglopend, maar nie minder tragies nie.

Die geskiedenis van die chemie van geneesmiddels oor die afgelope dekades illustreer paslik hoe chemici wêreldwyd hulle innoverende bekwaamhede tot die diens van die mensdom ingespan het. Vandag, in die eeu van biotegnologie, hoor ons gereeld van die kloning van gene, genetiese manipulasie en biosintese. Ons het baie te leer van die volksgeneeskundige van ouds wat onwrikbare vertroue gehad het in die deugsaamheid van sy middels. Gelukkig het ons iets anders ook geleer - ons het ons losgemaak van die ongeorganiseerde werkswyse van die volksgeneeskundige wat op sy eie te werk gegaan het, en ons het die sin om kragte saam te snoer in 'n multidissiplinêre span raakgesien.

Om die droom van die ideale geneesmiddel te verwesenlik, is geloof in die droom, perspektief op die probleme, entoesiasme en volgehoue toewyding nodig.

\section{Historiese oorsig en ontwikkeling van geneesmiddels}

\author{
E.C. Meyer \\ Departement Farmakologie, Universiteit van Pretoria, Pretoria 0002
}

Die oorsprong van farmakologie kan vir sover as 7000 jaar terug nagevors word. Vroeë farmakologie het uit die mens se soeke na genesing ontwikkel en is deur bygelowe, kwaksalwery en Boererate beïnvloed.
Talle belangrike geneesmiddels wat tans nog in gebruik is, het eeue gelede die natuur as ontstaansbron gehad. Opium, byvoorbeeld, is al 7000 jaar bekend. Ewe-eens is die salisilate en digitalis ook reeds vir 
enkele eeue in gebruik; so ook kinabas, as die eerste spesifieke antimikrobemiddel, wat vir etlike eeue in Peru by die behandeling van malaria aangewend is.

Tydens Paracelsus (1493-1541) se bloeitydperk aan die begin van die Renaissance was die hoofdoelstelling van chemie 'n soektog na die "filosoof se steen" - 'n fiktiewe gelukbringer wat goud sou kon skep en ewigdurende jeug sou bewerkstellig. Paracelsus het chemie as bondgenoot van geneeskunde aangewend met die woorde: “. . . die doel van chemie is geneeskunde". Dit was eers in die agtiende en negentiende eeu dat chemiese kennis so ontwikkel het dat dit 'n betekenisvolle bydrae tot farmakologie kon maak. Isolasie in relatief suiwer vorms van die aktiewe bestanddele van rou geneesmiddels het farmakologie as studieveld tot gevolg gehad. Die sintese van ureum deur Wöhler in 1929 het 'n tydvak met verreikende gevolge vir organiese chemie ingelui. Miljoene skeppings is mettertyd ontdek wat farmakologies evalueer moes word. Die farmakoloog was en is steeds geskik om die wetenskaplike gaping tussen die chemikus en die klinikus te oorbrug.

Die historiese ontwikkeling van farmakologie $k$ an in verskillende fases ingedeel word. Verskillende groepe geneesmiddels wat tans bemark word, se ontstaan is aan blote empiriese waarnemings te danke. 'n Tydperk van sistematiese chemiese wysigings van bekende middels en natuurprodukte het tussen 1935 en 1965 gevolg. Vanaf 1965 is geneesmiddels wat meer selektief ten opsigte van verlangde eienskappe is, ontwikkel. Farmakologie het baie bygedra en is steeds besig om by te dra tot biochemiese ontwikkeling en andersom. Die kennis van farmakokinetika het betekenisvol uitgebrei en tot rasionele geneesmiddelgebruik bygedra.

Waardevolle toekomstige ontwikkelings is alleen moontlik indien nuwe verbindings die vlak van chemiese waarneming bereik. Die farmakoloog moet ook skeptisisme ten opsigte van volksmedisyne laat vaar, sodat nuwe klasse geneesmiddels moontlik word.

\section{Die ontwikkeling, vervaardiging en bemarking van geneesmiddels}

F.O. Snyckers

Noristan Bpk., Silverton 0184

Die ontwikkeling, vervaardiging en bemarking van medisyne dek 'n baie wye spektrum. 'n Beknopte oorsig van hierdie multidissiplinêre veld word gegee en sekere uitslaggewende en moontlik minder bekende aspekte word uitgelig. 'n Paar gedagtes word ook gegee i.v.m. die kostestruktuur en die bemarkingstegnieke van medisyne.

Die beginpunt van die ontwikkeling word gedefinieer deur die bestaan van 'n chemies gedefinieerde en farmakologies interessante stof.

Die fases van ontwikkeling nl. chemiese toetsing, voorkliniese fases i \& ii, kliniese fases i, ii \& iii, registrasie, vervaardiging en verkope word verduidelik.

Volgens Duitse gegewens (1985) verg dit tot 10000 sinteses en 200 miljoen rand om een nuwe geneesmiddel te ontwikkel. Die kosteverdeling van die ontwikkelingsfases word analiseer as: $28 \%$ innovering, $25 \%$ werksaamheidsbewys, $30 \%$ veiligheidstoetsing en $17 \%$ prosesontwikkeling.

Sekere besondere ontwikkelingspunte word uitgelig:

\section{Patentering:}

Soos reeds genoem, verg dit astronomiese bedrae om 'n st of te ontwikkel, en dit teen 'n groot risiko. Geen kommersiële onderneming sal so iets kan of wil aanpak nie, tensy daar 'n redelike tydperk van gebruiksmonopolie deur 'n patent gewaarborg word.
2. Vereistes vir kommersiële sukses:

Kommersiële sukses verg tegnologiese sukses, maar nog heelwat meer. Dit vereis dat die nuwe geneesmiddel die mark suksesvol sal binnedring deur of ' $n$ nuwe marksegment oop te maak of bestaande middels te verplaas. Minder as een uit vyf nuwe produkte wat wel bemark word, is werklik suksesvol.

3. Chemiese bereidingsmetodes:

Voordat daar met die volskaalse farmakologiese ontwikkeling begin kan word, moet 'n metode van bereiding gevind word wat herhaalbaar en doeltreffend is en wat met die minimum koste gepaard gaan.

4. Prosesontwerp en validasie:

Vervaardigingsprosesse moet so ontwerp word dat herhaalbaarheid gewaarborg kan word.

5. Vervaardiging:

'n Stapsgewyse oorsig van 'n tipiese vervaardigingsproses word gegee. Beheer van sowel proses as produk speel ' $n$ kernrol in alle vervaardigingsaktiwiteite.

\section{Bemarking:}

Geen nuwe medisyne sal sy plek in die hoogs mededingende mark vind tensy sy voordele en eienskappe aan die verbruiker (in hierdie geval meesal die geneesheer) duidelik gestel word nie. Die hoofbemarkingskoste gaan aan 'n firma se mediese verteenwoordigers. Hierdie goedgeskoolde mense dien as die hoofskakel tussen die 
firma en die mediese en farmaseutiese professies. Die verteenwoordiger speel ook ' $n$ wesenlike rol in die monitering van newe-effekte. 'n Verdere bemarkingsuitgawe is die ondersteuning van mediese en ander vakkundige kongresse, lesings en navorsingsprojekte.

Daar bestaan 'n bindende gedragskode vir die bemarking van medisyne, 'n kode waartoe alle lede van die Farmaseutiese Vervaardigersvereniging hulle verbind het. Die kode vereis dat alle bemarkingsaktiwiteite streng voldoen aan die etiese reëls van die S.A. Aptekersraad, aan die reëls van die Gesagsvereniging van Reklamestandaarde en aan die Wet op die Beheer van Medisyne en Verwante Stowwe.

7. Fase IV - Opvolg en monitering:

Alle middels wat ' $n$ vervaardiger in die mark het, is onderworpe aan 'n deurlopende monitering vir enige gevalle van newe-effekte.

8. Prysstruktuur en prysstygings van geneesmiddels: Die beskuldiging dat die Suid-Afrikaanse farmaseutiese bedryf buitensporige winste maak, is reeds deur 'n aantal kommissies ondersoek (onlangs deur die BROWNE-kommissie). Daar is telkens bevind dat daar geen gronde vir so ' $n$ beskuldiging is nie. Dit is ook nie waar dat medisynepryse buite verhouding met die inflasiekoers styg nie. Omdat die meerderheid van alle insetmateriale ingevoer word, is hulle onderhewig aan die effek van die dramatiese verval van die waarde van die rand.

'n Analise van die kostestruktuur van 'n groep geneesmiddels toon 'n wins van $12 \%$. Die winsaandeel word tot 'n groot mate gebruik vir die herinvestering in vervaardigingstoerusting.

\title{
Biologiese aktiwiteit en chemiese struktuur
}

\section{D.P. Venter}

Departement Farmakologie, Potchefstroomse Universiteit vir Christelike Hoër Onderwys, Potchefstroom 2520

Een van die groot drome van die medisinale chemikus is die "rasionale ontwerp" van geneesmiddels. Dit sou wonderlik wees om te begin met die basiese biochemie en molekulêre biologie van 'n patogene toestand en dan met groot vertroue 'n organiese verbinding te sintetiseer wat in staat sou wees om die patogene toestand te korrigeer sonder ernstige newe-effekte. Ongelukkig sal hierdie droom vir 'n lang tyd slegs 'n droom bly.

Die metodologie van geneesmiddelontwerp kan grootliks verbeter as ons meer van reseptore en hulle wyse van interaksie met geneesmiddels geweet het. Sulke inligting sou byvoorbeeld gebruik kon word om konformasioneel gedefinieerde strukture te ontwerp waarin farmakofore in 'n gepaste ruimtelike rangskikking vir optimale reseptorinteraksie georienteer is. Alhoewel die presiese aard van reseptore nog onbekend is, is die "chemiese struktuur" van reseptore waarskynlik steries komplimentêr aan die struktuur van endogene en eksogene stowwe waarmee dit interageer.

Korrelasies tussen biologiese aktiwiteit en chemiese struktuur word verkry deur eksperimentele data vir reekse geneesmiddels wat op dieselfde soort reseptore inwerk, te bepaal. Daar word dan gepoog om hipoteties aktiewe sentra vir reseptore te konstrueer. Daar moet met groot omsigtigheid te werk gegaan word met die toekenning van so 'n veronderstelde model, aangesien nuwe bevindings noodwendig tot hersiening lei en die waarde van so 'n model as werkshipotese soms bevraagteken kan word.

Die probleem wat dus telkens opduik, is dat in baie gevalle aanvanklik 'n bepaalde verwantskap tussen struktuur en aktiwiteit verkry word, maar met die uitbreiding van die chemiese navorsingsgebied word hierdie struktuuraktiwiteitsverwantskap ietwat vaag. Dit is dus duidelik dat die graad van vryheid in die chemiese struktuur baie groter is as wat aanvanklik vermoed is.

Wat ons kennis van die reseptorstruktuur en geneesmiddel-reseptorinteraksies aanbetref, het hierdie metode tot baie verwarring gelei. Ten spyte van hierdie ooglopende tekortkominge van struktuuraktiwiteitsverwantskapstudies, het hierdie tipe studie groot waarde by die ontwerp van potensieel nuwe geneesmiddels.

Hierdie aspek van geneesmiddelnavorsing ondergaan tans 'n geweldige verandering: in wese is hierdie verandering gekoppel aan die gebruik van rekenaars, die toepassing van fisies-organiese chemie, organiese en biochemiese reaksie meganismes, ens. in medisinale chemie.

\section{Neurofarmakologie: Biochemiese aspekte}

\author{
T.J. van de Merwe
}

Departement Psigiatrie, Universiteit vạn Pretoria, Pretoria 0002

Neurofarmakologie is die studie van middels met werking spesifiek gerig op die senuweestelsel.
Prakties betrek dit 'n wye gebied: narkosemiddels en terapeutiese gasse, hipnotika en sedeermid- 
dels, alifatiese alkohole, middels gebruik by psigiatrie, epilepsie en Parkinsonisme asook die opioïed analgetika en antagoniste, sentralesenustelselstimulante, verslawende middels van verskillende aard en die outonome senuweestelselpreparate.

Vanweë die kompleksiteit van dié veld integreer die klinikus navorsingsbydraes vanuit verskeie dissiplines. Makro- en mikroskopiese neuroanatomie, neurofisiologie, biochemie, patofisiologiese prosesse in psigiatriese en neurologiese siektes, bydraes vanuit die sielkundige gedragswetenskappe sowel as dierkunde en farmakologie lê die grondslag vir hipotesestelling en empiries fundeerde behandelingsmetodes.

Biochemiese beginsels kan beter begryp word deur toegepaste kennis van die topografiese kartering van die brein en begrip van die interverwantskappe van breinstrukture. Die limbiese sisteem vorm die neuronale basis vir die emosies. Hipotalamiese en hipofisêre neurohumorale funksies skakel eweneens in by kortikale en subkortikale funksies te doene met kognisie, emosie en gedrag. So ook die outonome sisteem met komplekse neurofisiologiese funksies. Breinfunksie is voortvloeiend uit die interaksie van geïntegreerde neuronale sisteme.

Die neuron is die funksionele eenheid van die brein. Geleiding in die neuronakson vind plaas deur polariseringsverskynsels op ioonvlak. Sel-tot-selkontak vind plaas deur die sinaps. Oordrag in die sinaptiese spleet is hoofsaaklik deur neurooordragstowwe. Pre- en postsinaptiese reseptorfunksie met kaskade van intrasellulêre en selwand gebeure word gestimuleer.

Bekende neurotransmitters is dopamien, noradrenalien, serotonien, GABA (gamma-amino-bottersuur) en glisien. Die katesjolamiene en indoolamiene speel ' $n$ belangrike rol in die patofisiologie van onder andere Parkinsonisme, die affektiewe versteu- rings en skisofrenie.

Dopamien as katesjolamienprototipe word vervaardig vanuit tirosien. Intrasellulêr en in die sinaptiese spleet vind katabolisme hoofsaaklik deur oksidatiewe de-aminasie en transmetilering plaas. Spesifieke dopamienneuronbane word verteenwoordig deur die nigrostriatale verbindingsbaan (motoriese funksie), die tuberoinfundibulêre sisteem (neurohumorale funksies) en die mesolimbieskortikale vesels met hoofsaaklik psigiese funksies. Laasgenoemde word betrek by die patofisiologie van skisofrenie.

Organiese hipoteses oor skisofrenie sluit onder andere die dopamienhipotese in. Drie variante bestaan. 'n Oormaat dopamien mag beskikbaar wees by sinapse; of 'n verhoogde aantal postsinaptiese reseptore of verhoogde postsinaptiese reseptoraffiniteit bestaan; of die interaksies tussen dopamien, asetielcholien en GABA mag versteur wees.

Farmakologies bied hierdie hipotese 'n raamwerk vir die gebruik van antipsigotiese middels. Fenotiasiene, buterofenone en tioksantene affekteer die dopamiensisteem deur postsinaptiese reseptorblokkade. Die "ooraktiwiteit" van dopamien word sodoende farmakologies geïnhibeer. Newe-effekte van hierdie middels is dus ook die gevolg van dopamienreseptorblokkade en word hoofsaaklik gevind in ekstrapiramidaal-motoriese en neurohumorale disfunksies.

Samevattend dui hierdie voorbeeld op die interverwantskap van die makroskopiese en mikroskopiese neuranatomie van die dopaminergesisteem, met integrasie van biochemiese gebeure in die selwand en sinaptiese spleet. Dit bied 'n raamwerk waarin hipoteses oor patofisiologiese prosesse ontwikkel kan word en vandaar behandelingsgronde deur farmakologiese manipulasie.

\title{
Radiofarmaseutiese hart- en breinmiddels
}

\author{
A.J. van Wyk \\ Isotoopproduksiesentrum, Atoomenergiekorporasie van Suid-Afrika, Posbus 582, Pretoria 0001
}

Radiofarmasie is die fundamentele dissipline wat aan kerngeneeskunde primêre radioisotope asook radioisotoopgemerkte middels beskikbaar maak vir kliniese in vivo-toepassings d.m.v. gammakameras. Hierdie middels word veral gebruik vir diagnose en soms ook terapie van verskeie siektetoestande. Die Isotoopproduksiesentrum (IPS) van die AEK lewer jare lank 'n nasionale diens t.o.v. produksie en landswye verskaffing van radioisotope veral vir mediese gebruik. In dié verband is die belangrikste produk die sogenaamde Mo-99/Tc-99m-moederbron vir die verskaffing van $\mathrm{Tc}-99 \mathrm{~m}$, wat onmisbaar is vir die formulering van orgaanspesifieke radioisotoopgemerkte verbindings. Hierdie radioisotoop het 'n ideale energie van $140 \mathrm{KeV}$ en halfleeftyd van 6 uur, wat baie geskik is vir orgaanbeelding. Sy chemie is egter kompleks weens die baie valensstate (vanaf -1 tot $+7)$ wat moontlik is. Deur verskillende ligande en reduseermiddels te gebruik, is 'n verskeidenheid van orgaanspesifieke middels reeds ontwikkel. Nuwe deurbrake in radiofarmaseutiese chemie is onlangs gemaak wat betref nuwe kliniesbruikbare Tc-99m gemerkte hart- en breinmiddels, byvoorbeeld: Tc99m-heksametielpropileenamienoksiem (HMPAO) is ontwikkel vanaf propileenamienoksiem (PAO) en beantwoord grootliks aan die vereistes vir ' $n$ ideale breinmiddel, nl. breinopname volgens bloedvloei, hoë ekstraksiedoeltreffendheid, minimale herdistribusie en voldoende breinretensie. In die geval van Tc-99m-HMPAO is daar 'n verskil tussen die verskillende isomere t.o.v. breinopname, bv. die d,ldiastereomere paar is beter as die meso-isomeer. 
Hoewel hierdie regionale serebrale bloedvloeimiddel slegs sowat $7 \%$ absolute breinopname tydens kliniese studies toon, kan tot $20 \mathrm{mCi}$ toegedien word weens die goeie dosimetrie van Tc-99m om uitstekende beelde te verseker. Verskeie siektetoestande soos breintumore, infarksie, epilepsie, Alzheimersiekte, ens. kan bestudeer word.

'n Verdere ontwikkeling is dié van sg. NEPDADT (N-etielpiperidiniel-diaminoditiol) en sy metielanaloog wat goed opruim uit die bloed en dus 'n goeie brein-tot-agtergrond-verhouding verseker.

Hoewel T1-201 reeds lankal gebruik word as miokardiale perfusiemiddel vir die studie van infarksie, ens., bestaan daar sekere nuklidiese en metaboliese tekortkomings, bv. herdistribusie, nieideale nuklidiese eienskappe vir beelding en dosimetrie, relatiewe hoë koste en lae beskikbaarheid. Daar is dus daadwerklik gepoog om bruikbare Tc-99mekwivalente te ontwikkel en onlangs is belowende isonitriele wel verkry, nl. TBI (ters. butielisonitriel), CPI (karbometoksie isopropielisonitriel) en MIBI (metoksie isobutielisonitriel). Hoewel Tc-99m-TBI duidelike hartopname toon, is daar ook ongewenste hoë long- en leweropname, met retensie asook herdistribusie. Die isonitrielester Tc-99m-CPI toon laer long- en leweropname, maar ook stadige hartuitwassing. Die isonitrieleter Tc-99m-MIBI toon relatiewe lae long- en leweropname met voldoende miokardiale retensie om tot 'n goeie teiken-tot-agtergrondverhouding te lei. Hierdie belowende miokardiale verbinding het dus beter nuklidiese eienskappe as T1-201, aanvaarbare biologiese eienskappe en is ook baie meer beskikbaar.

Die toekomstige groei van kerngeneeskunde berus nie net op verbetering van apparatuur nie, maar veral op die verdere chemiese ontwikkeling van nuwe orgaanspesifieke en metaboliese radiofarmaseutiese middels.

\title{
Antikankermiddels
}

\author{
A.S. Alberts \\ Departement Mediese Onkologie, Universiteit van Pretoria, Pretoria 0002
}

Die belangrikheid van antikankermiddels word geilllustreer deur die feit dat een uit elke 4 mense kanker kry en dat een uit elke 5 mense aan kanker sterf. Kanker is die tweede-algemeenste oorsaak van dood by volwassenes en kinders. Met die ingebruikneming van chemoterapie het die sistemiese behandeling van kanker moontlik geword en tesame met die verbeterings in die ander modaliteite het die 5-jaar-oorlewingsmoontlikheid van alle kankerpasiënte in 1984 tot meer as $50 \%$ gestyg.

Die tydperk van moderne kankerchemoterapie het met die Eerste en Tweede Wêreldoorlog begin, nadat die lokaal-irriterende en sistematiese toksiese eienskappe van mosterdgas ontdek is. In 1952 is die eerste antimetaboliet, aminopterin, en kort daarna metotreksaat vrygestel. Daarna het veelvuldige middels gevolg waarvan vele 'n belangrike plek in kankerterapie verkry het.

Antikankermiddels werk deur DNA-sintese of -funksie te belemmer. Puriensintese word deur 6-merkaptopurien en 6-tioguanien belemmer. Metotreksaat, 5-fluorourasiel en hidroksie-ureum verhoed die vorming van deoksiribonukleotiedes vanaf die ribonukleotiedes. Sitarabien verhoed die vorming van deoksiribonukleïensuur (DNS) vanaf deoksiribonukleotiedes. Alkileermiddels veroorsaak kruisbinding in die DNS-ketting. Doksorubisien, daunorubisien, aktinomisien-D en mitramisien veroorsaak interkalasie van DNA. Blemisien beskadig DNA en verhoed dat DNS herstel. Prokarbasien depolimeriseer DNS. L-asparaginase deamineer $\mathbf{L}$-asparagien wat die sintese van proteiene in die sel belemmer. Die vinka-alkalö̈ede inhibeer seldeling deur die mikrotubules te inhibeer.
Daar is geen unieke biochemiese paaie of molekules in die kankersel nie. Selektiewe toksisiteit vir antikankermiddels is alleen moontlik weens die hoë groeifraksie van maligneselle - dit wil sê dat 'n hoë persentasie van kankerselle in 'n tumor besig is met, verdeling en dan sensitief is vir middels. Ongelukkig is sekere normale weefsel soos die beenmurgselle, slymvliesselle van die mond, selle van die haarfollikels en die kiemselle in die testis en eierstokke ook verdelend. Dit gee aanleiding tot die hoë insidensie van newe-effekte met behandeling met die middels.

Om die selektiewe toksisiteit te verbeter, word van kombinasiechemoterapie gebruik gemaak. Daarin word byvoorbeeld 3 of 4 antikankermiddels saamgevoeg - elkeen met 'n afsonderlike toksisiteit, maar met dodelike effek op die kankersel. Ander moontlikhede sluit in die toediening van antikankermiddels in baie hoë doserings wat nie-selektief kankerselle en normale selle vernietig. Met ondersteuning in kiemvrye kamers met antibiotiese dekking en bloedoortappings word beenmurgselle vanaf 'n geskikte skenker vir die pasiënt "oorgeplant" met die gevolglike genesing van die pasiënt.

Die primêre mikpunt bly nog steeds om middels te vind wat net die kankerselle sal aantas. Om dit te kan doen moet unieke karaktereienskappe by die kankerselle gevind word. Daar is al daarin geslaag om antiliggame te vervaardig wat die kankerselle as vreemd herken en spesifiek daaraan bind. Heelwat navorsing word gedoen om radioaktiewe of antikankermiddels aan hierdie antiliggame te koppel wat dan selektief na die kankerselle gedra word. Die biologiese responsmodifiseerders is middels wat 
kankerselle direk kan aantas of die liggaam se eie weerstand spesifiek teen die kankerselle kan stimuleer.

Indien 'n kind 20 jaar gelede 'n akute limfatiese leukemie sou opdoen, was sy kans op genesing $0 \%$. Tans is die kans op genesing meer as $60 \%$. ' $n$ Reusetaak lê voor, maar ons kan met trots terugkyk op wat reeds bereik is.

\title{
Die chemie van antimikrobemiddels
}

\author{
De K. Sommers \\ Departement Farmakologie, Universiteit van Pretoria, Pretoria 0002
}

Met die uitsondering van die arsfenamiene vir die chemoterapie van sifilis was daar tot die middel van die 1930's geen middel vir die sistemiese behandeling van bakteriële siektes nie. In die laat-negentiende eeu het die differensiële kleuring van weefsels en bakterieë die basis vir vroeë chemoterapeutiese navorsing gevorm. Aanvanklik was hulle aanwending tot malaria beperk, maar in 1932 word sulfamidokrisoidien of Prontosil, 'n asokleurstof met sulfamielgroepe wat goed aan bakterieë kleef, deur twee Duitse wetenskaplikes gepatenteer. Die ontdekking van sulfanilamied as metaboliet van Prontosil baan die weg vir die ontwikkeling van verskeie sulfoonamiede en lei die begin van die antibakteriële chemoterapeutiese era in.

Die ontdekking van penisillien in 1928 en die demonstrasie van sy veiligheid en terapeutiese waarde in 1940 , gee aanleiding tot uitgebreide programme vir die sifting van swamme en bakteriee. Vervolgens word daar tussen die jare 1940 en 1960 die aanvangsvoorbeelde van al die belangrike klasse antibiotika gevind. In die daaropvolgende twintig jaar word baie derivate van hierdie primêre antibiotika deur biosintese of semisintese ontwikkel. Hierdie semisintetiese of biosintetiese benadering tot die ontdekking van analoë van bestaande antibiotika genereer steeds hoogs effektiewe middels en daar is inderwaarheid geen geheelnuwe chemiese entiteit in onlangse lyste van antimikrobemiddels nie.

Die nie-klassieke $\beta$-laktaamantibiotika verteenwoordig waarskynlik die belowendste klas van ver- bindings. Hulle is die kefamisiene, die klavame, die karbapenems en die monobaktame. Met hierdie middels is daar tot 'n groot mate stabiliteit teen Gram-negatiewe $\beta$-laktamases verkry en die hoofmeganisme van weerstandigheid by Gram-negatiewe organismes is tans antibiotiese uitsluiting. Weerstandsmeganismes eie aan Gram-positiewe organismes is veranderinge in die skyfproteïene en dié wat inmeng met die litiese werking van die antibiotikum. 'n Grondiger kennis van die karboksipeptidasestranspeptidases betrokke by selwandsintese kan tot verdere rasionele $\beta$-laktaam ontwerp lei.

Dit is ironies dat die kinoloonantimikrobemiddels, wat terapeuties geringskat is, skielik die potensiaal het om 'n belangrike deel van die chemoterapeut se armamentarium uit te maak. Nalidiksiensuur is in die 1970's gevolg deur pipemiedsuur wat 'n effens vermeerderde antibakteriële aktiwiteit getoon het, maar dit was die sintese van die nuwere 4-kinolone soos norfloksasien en siprofloksasien wat werklik belangwekkend is. Hulle dood die meeste Enterobacteriaceae en ook PS. aeuruginosa by relatief lae konsentrasies. Ander spesies wat gevoelig is, is $H$. influenzae en metisillienweerstandige stafilokokke. Weerstandigheid ontwikkel ook stadig teen hierdie nuwe kinolone en newe-effekte is op die agtergrond.

Die grootste uitdaging in die toekoms is sekerlik om nuwere dideoksiennukleosiede, kragtiger en minder toksies as asidotimidien, en ander chemoterapeutika teen die VIGS-virus te ontwerp.

\section{Toekomstige Byeenkomste}

- Die 30ste Konvensie van die Suid-Afrikaanse Chemiese Instituut vind van 15-20 Januarie 1989 in Johannesburg plaas. Die tema is Chemie vir Suider-Afrika. Die doel met dié tema is om almal wat ' $n$ belangstelling in chemie het, byeen te bring en sodoende die teorie, praktyk en onderrig van die vak in die subkontinent te bevorder. Navrae i.v.m. die Wetenskaplike Program kan gerig word aan mev. L.H. Lötter by
(011) 728-7373.

- Die Entomologiese Vereniging van Suidelike Afrika se kongres word van $10-13$ Julie 1989 by die Universiteit van Natal, Pietermaritzburg gehou. Alle aspekte van entomologie en aragnologie sal bespreek word. Die kongres word georganiseer deur dr. J. Londt, Natal Museum, Loopstraat 237, Pietermaritzburg 3201. 